\title{
Retinoids Issued from Hepatic Stellate Cell Lipid Droplet Loss as Potential Signaling Molecules Orchestrating a Multicellular Liver Injury Response
}

\author{
Marie Bobowski-Gerard ${ }^{+}{ }^{\mathbb{D}}$, , Francesco Paolo Zummo ${ }^{\dagger}$, Bart Staels, Philippe Lefebvre ${ }^{\ddagger}$ \\ and Jérôme Eeckhoute $*, \ddagger$ (D) \\ Institut Pasteur de Lille, The University of Lille, Inserm, CHU Lille, U1011-EGID, F-59000 Lille, France; \\ marie.gerard@inserm.fr (M.B.-G.); francesco.zummo@inserm.fr (F.P.Z.); bart.staels@pasteur-lille.fr (B.S.); \\ philippe-claude.lefebvre@inserm.fr (P.L.) \\ * Correspondence: jerome.eeckhoute@inserm.fr; Tel.: +33-032-097-4220 \\ † Joint first authors. \\ $\ddagger$ Joint senior authors.
}

Received: 3 September 2018; Accepted: 13 September 2018; Published: 13 September 2018

\begin{abstract}
Hepatic stellate cells (HSCs) serve as the main body storage compartment for vitamin A through retinyl ester (RE)-filled lipid droplets (LDs). Upon liver injury, HSCs adopt a myofibroblastic phenotype characterized by an elevated expression of extracellular matrix proteins and a concomitant loss of LDs. On the one hand, LD breakdown has been suggested to provide the energy required for HSC activation into myofibroblast-like cells. On the other hand, this process could mitigate HSC activation following the transformation of released REs into retinoic acids (RAs), ligands for nuclear receptors exerting antifibrotic transcriptional regulatory activities in HSCs. Importantly, RAs may also constitute a means for HSCs to orchestrate the liver response to injury by triggering transcriptional effects in multiple additional surrounding liver cell populations. We envision that new approaches, such as single-cell technologies, will allow to better define how RAs are issued from LD loss in HSCs exert a multicellular control of the liver (patho)physiology.
\end{abstract}

Keywords: liver; hepatic stellate cells; lipid droplet; retinoids; liver injury; intercellular communications

\section{Introduction}

While the liver is composed mainly of hepatocytes, additional less abundant cell-types also contribute significantly to hepatic (patho) physiology. Hepatic stellate cells (HSCs), which are localized within the space of Disse between endothelial cells and hepatocytes, are mesenchymal-like cells making up about $10 \%$ of the total liver cell population [1]. Upon liver injury, HSCs undergo an "activation" process, described as a "transdifferentiation" towards a myofibroblast-like phenotype accompanied by a loss of the lipid droplets (LDs) characterizing their quiescent state [2]. Activated HSCs synthesize large amounts of ECM proteins, such as type I and type III collagen, and are therefore key players in the resolution of liver injury. However, uncontrolled HSC activation is a major contributor to liver fibrosis, which has put a spotlight on this cell type within the last decades [3].

\section{Mechanisms of LD Loss and Requirement for HSC Activation}

While the loss of LDs is a key feature of HSC activation, many questions remain as to how and why these LDs disappear from HSCs. Several pathways related to lipid metabolism have been suggested to account for LD loss upon activation. First, LD loss could be due to a modification of the activity of the enzymes involved in LD synthesis and/or degradation through pathways well known to be involved in 
the breakdown of adipose tissue LDs, including adipose triglyceride lipase/patatin-like phospholipase domain containing 2 (PNPLA2/ATGL) [4,5]. PNPLA3, whose expression is increased upon HSC activation, has also been shown to be involved in LD breakdown [6,7]. In addition, many recent studies have highlighted a role for autophagy in lipid release from HSCs that could help the myofibroblastic transition $[3,8]$. For instance, reactive oxygen species (ROS), produced by damaged hepatocytes, can induce autophagy through Rab25 and trigger LD disappearance in HSCs [9].

It has been suggested that LD loss could support the HSC activation process essentially by providing energy (Figure 1). Indeed, the hydrolysis of triglycerides provides the cell with free fatty acids (FFAs) that can undergo mitochondrial $\beta$-oxidation to generate the ATP necessary for the acquisition of the myofibroblastic phenotype, including the production of $\alpha$-sma and collagen fibers [10]. However, novel approaches to detect and quantify LDs showed that while activated HSCs isolated from bile duct ligation (BDL)-injured mice display smaller LDs in diameter, the number of LDs remains similar to healthy livers [11]. In line with this observation, lipidomic analysis revealed the apparition of "new" LDs in activated HSCs that contain less RE, but are enriched in triacylglycerol compared to the "original" LDs found in quiescent HSCs. These new LDs are thought to migrate to the cell periphery and to be smaller in size $[12,13]$. Moreover, LD REs are not lost until day 4 in spontaneously activated primary HSCs in vitro after transdifferentiation has already been initiated [11]. Finally, mice deficient for the lecithin retinol acyltransferase (Lrat) gene, encoding an enzyme converting retinol to its RE storage form [14], lack RE-filled LDs but are not predisposed to spontaneous or acute exacerbation of fibrogenesis, suggesting that the loss of LDs may not be sufficient to trigger liver fibrosis [14,15].

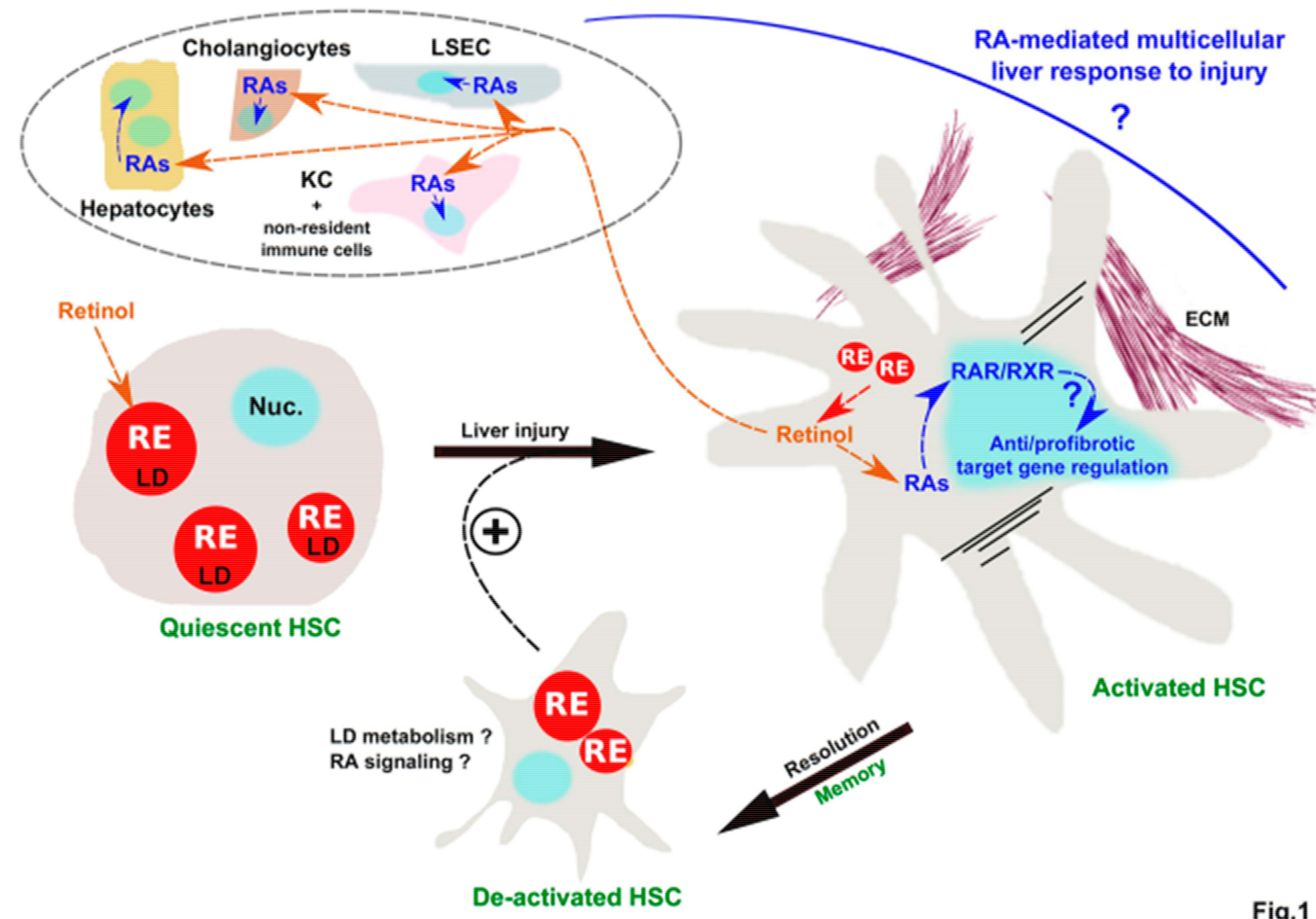

Figure 1. Potential role of RAs derived from the loss of RE-filled HSC LDs as an orchestrator of a multicellular response to liver injury. Schematic showing the basis for the proposal that RAs derived from the loss of RE-filled LD upon HSC activation may define a multicellular response to liver injury. Outstanding questions are indicated by question marks. See text for details. ECM, extracellular matrix; KC, Kupffer cells; LD, lipid droplet; LSEC, liver sinusoidal endothelial cells; Nuc., nucleus; RE, retinyl ester; RAs, retinoic acids. 
All together, these data indicate that energy provided by LD loss may not be required to initiate HSC activation, but may rather serve to sustain activation (perpetuation phase). Importantly, LDs in quiescent HSCs are filled with REs, which are released upon LD loss and can give rise to transcriptionally active retinoids. We postulate that this unique feature may represent a key signaling event within HSCs and surrounding liver cells upon the loss of RE-filled LD.

\section{Control of HSC Activation through Retinoids Issued from LD Loss}

Vitamin A must be acquired from the diet either as REs (animal origin) or provitamin A carotenoids (vegetal origin). Unlike most vitamins, retinol can be stored within the body at relatively high levels, probably to prevent vitamin A deficiency [16]. This storage occurs primarily in HSCs $(\sim 80 \%$ of total vitamin A) under the form of REs in LDs. This allows the liver to provide the peripheral tissues with sufficient vitamin A for months, even when dietary intake is not sufficient, through the release of retinol-bound retinol-binding protein (RBP) into the circulation. The rapid uptake of retinol by peripheral tissues is followed by its processing into active metabolites such as retinal or retinoic acids (RAs), which are instrumental to many processes including vision (pigment formation in the eyes), reproduction, growth, development, immunity and metabolism including adipose tissue metabolism [17]. Of note, many epidemiological studies have reported vitamin A deficiency in chronic liver diseases such as viral hepatitis and non-alcoholic fatty liver disease (NAFLD) $[17,18]$. For instance, an inverse correlation between liver retinol levels and the progression of NAFLD, as judged by histological classification of the disease, has been demonstrated [19] and could illustrate the loss of RE-filled LDs upon HSC activation. This leads to unbalanced retinol levels in the circulation and several organs.

Within HSCs, the retinol generated by RE hydrolysis can be metabolized into retinal through alcohol dehydrogenases (ADHs) and subsequently metabolized into RAs by retinal dehydrogenases (RALDHs) [20]. RAs derived from vitamin A can bind to the retinoic acid receptors (RAR $\alpha, \beta$ and $\gamma$ ) and/or retinoid X receptors ( $R X R \alpha, \beta$, and $\gamma$ ), transcription factors (TFs) of the nuclear receptor (NR) superfamily. Importantly, RXRs can regulate the activity of various other NR family members by formation of heterodimers. Different studies using synthetic RAR/RXR ligands have been performed in order to monitor how these TFs can modulate HSC activation and gene expression. In rodents, RAs have been shown to exert antifibrotic activities [21-23]. This is in line with in vitro studies showing that the expression of pro-fibrogenic genes such as collagen, type I, alpha 1 (Col1a1) or actin, alpha 2, smooth muscle, aorta (Acta2 or $\alpha$-sma) decreases upon exposure of HSCs to RAR/RXR activators $[17,18]$. Note, however, that specific effects are exerted by different RAs [24]. Moreover, while LRAT shows decreased expression/activity during HSC activation [15,25], RAs could oppositely increase Lrat mRNA expression through the presence of an RA responsive element in its promoter [16]. Indeed, inactivation of HSCs by RAs is associated with the recovery of large LDs, a feature of quiescent/de-activated HSCs. This may be due to both stimulation of LD synthesis and inhibition of their breakdown by autophagy; the latter involving modulation of LD-associated proteins [8]. Besides studies using synthetic RAs, indirect evidence that RAs modulate HSC activation also exists. For instance, the PNPLA3 I148M variant, found in NAFLD patients, leads to reduced retinol levels and RA signaling in HSC together with a profibrogenic phenotype [6]. Moreover, Adh3 deficiency in the mouse exacerbates both liver fibrosis and the expression of profibrotic genes in HSCs [26].

All together, these observations strongly suggest that RAs release upon LD loss upon HSC activation could serve as a feedback loop mitigating HSC activation. This might be relevant to liver fibrosis resolution, which involves the reversion of a fraction of activated HSCs to a quiescent-like (de-activated) phenotype (Figure 1) $[27,28]$. However, the precise molecular mechanisms have not been investigated and whether the decreased expression of HSC activation markers results from direct transcriptional regulatory effects and/or indirectly results from modulation of LD metabolism remains to be defined. 


\section{Retinol Released by LD Loss as A Potential Cross-Talk Signal Between HSC and Other Hepatic Cell Populations in Liver (Patho) Physiology}

Liver (patho)physiology relies on intercellular communications where the microenvironment is used to dialogue with surrounding cells $[3,29,30]$. While this has not yet been firmly established, we postulate that retinol release by HSC consecutive to LD loss may modulate activities of other cell types in the liver (Figure 1). Indeed, analyses of RAR/RXR cistromes and target genes in hepatocytes point to extensive crosstalk with key hepatic transcription factors in regulating both metabolic and housekeeping functions [31-34]. In line, synthetic RAs promote liver regeneration through induction of cell cycle gene expression in hepatocytes [35]. Further indications that endogenous RAs might be required for liver regeneration comes from $\mathrm{Lrat}^{-/-}$mice, which lack HSC retinoid stores in LDs and show delayed regenerative responses upon partial hepatectomy [36]. Moreover, selective ablation of $R X R \alpha$ in hepatocytes impairs their proliferative and regenerative potential [37]. Importantly, RARs and RXRs are widely expressed in the liver, not only in HSCs and hepatocytes, but also in cholangiocytes, liver sinusoidal endothelial cells (LSEC), and Kupffer cells [38-40]. We propose that RAs may exert protective effects upon liver injuries also through activities in non-parenchymal cells. Interestingly, although still sparse, some studies reported functional RA signaling in liver non-parenchymal cells. In Kupffer cells, RXR activation might reduce nitric oxide and TNF-alpha production [41]. RAs regulate cholangiocyte proliferation in response to cholestatic injury [42] and in LSECs, which express functional RALDHs, RA signaling is required for liver priming of a CD4+ T cell gut-homing phenotype [43]. Finally, vitamin A plays an important role in both innate and adaptive immune functions. Thus, in addition to the production of cytokines, HSCs may modulate the liver immunology system through RAs issued from LD loss [44]. In line, HSC's ability to produce RA is required to promote liver immune tolerance through promoting Tregs and suppressing Th17 differentiation [45].

Considering the biological effects of synthetic RAs on liver cell populations summarized here, the concept that retinol released by LD loss upon HSC activation might represent a protective mechanism is attractive. As retinol increases in the circulation following HSC activation, we envision that systemic effects may also occur.

\section{Conclusions and Future Perspectives}

While LD loss is the main feature of HSC activation, how this impacts on liver (patho)physiology remains a matter of debate. Indeed, LD loss might both fuel HSC activation by providing FFA-derived ATP and mitigate this process through RA signaling. How these two adverse consequences of LD loss concur to modulate HSC activation remains to be defined. RA signaling might, in addition, trigger protective responses in surrounding liver cells (Figure 1). Direct monitoring of RA signaling in the various liver cell populations upon injury and HSC activation might now be at reach using low/single-cell transcriptomic and cistromic analyses. Such investigations would undoubtedly help to clarify the potential role of RA signaling in the multicellular control of liver response to injury. Importantly, the consequences of disturbed liver retinol metabolism most probably differ in acute and chronic conditions, the second being potentially linked to vitamin A deficiency.

An important and still poorly defined feature of HSC is their potential heterogeneity. Indeed, this may translate to HSC subpopulations with different abilities to store RE in LD and to activate upon injury [46]. Here again, single-cell approaches might provide valuable insights. Interestingly, the reversal of HSC activation during liver fibrosis resolution gives rise to deactivated HSCs, which are different from quiescent HSCs as they keep the memory of previous activation and are more responsive to a second fibrogenic stimulus (Figure 1) [27,28]. Of interest would be to characterize LD metabolism and RA signaling in these deactivated HSCs to define how they relate to the memory effects leading to a higher responsiveness to recurring liver insult. 
Acknowledgments: This work was supported by grants from the Fondation pour la Recherche Médicale (Equipe labellisée, DEQ20150331724), “European Genomic Institute for Diabetes” (E.G.I.D., ANR-10-LABX-46), European Commission and the European Research Council (ERC Grant Immunobile, contract 694717).

Conflicts of Interest: The authors have no potential conflicts of interest to disclose.

\section{References}

1. Asahina, K.; Tsai, S.Y.; Li, P.; Ishii, M.; Maxson, R.E.; Sucov, H.M.; Tsukamoto, H. Mesenchymal origin of hepatic stellate cells, submesothelial cells, and perivascular mesenchymal cells during mouse liver development. Hepatology 2009, 49, 998-1011. [CrossRef] [PubMed]

2. Blaner, W.S.; O’Byrne, S.M.; Wongsiriroj, N.; Kluwe, J.; D'Ambrosio, D.M.; Jiang, H.; Schwabe, R.F.; Hillman, E.M.C.; Piantedosi, R.; Libien, J. Hepatic stellate cell lipid droplets: A specialized lipid droplet for retinoid storage. Biochim. Biophys. Acta 2009, 1791, 467-473. [CrossRef] [PubMed]

3. Tsuchida, T.; Friedman, S.L. Mechanisms of hepatic stellate cell activation. Nat. Rev. Gastroenterol. Hepatol. 2017, 14, 397-411. [CrossRef] [PubMed]

4. Tuohetahuntila, M.; Molenaar, M.R.; Spee, B.; Brouwers, J.F.; Houweling, M.; Vaandrager, A.B.; Helms, J.B. ATGL and DGAT1 are involved in the turnover of newly synthesized triacylglycerols in hepatic stellate cells. J. Lipid Res. 2016, 57, 1162-1174. [CrossRef] [PubMed]

5. Tuohetahuntila, M.; Molenaar, M.R.; Spee, B.; Brouwers, J.F.; Wubbolts, R.; Houweling, M.; Yan, C.; Du, H.; VanderVen, B.C.; Vaandrager, A.B.; et al. Lysosome-mediated degradation of a distinct pool of lipid droplets during hepatic stellate cell activation. J. Biol. Chem. 2017, 292, 12436-12448. [CrossRef] [PubMed]

6. Pingitore, P.; Dongiovanni, P.; Motta, B.M.; Meroni, M.; Lepore, S.M.; Mancina, R.M.; Pelusi, S.; Russo, C.; Caddeo, A.; Rossi, G.; et al. PNPLA3 overexpression results in reduction of proteins predisposing to fibrosis. Hum. Mol. Genet. 2016, 25, 5212-5222. [CrossRef] [PubMed]

7. Bruschi, F.V.; Claudel, T.; Tardelli, M.; Caligiuri, A.; Stulnig, T.M.; Marra, F.; Trauner, M. The PNPLA3 I148M variant modulates the fibrogenic phenotype of human hepatic stellate cells. Hepatology 2017, 65, 1875-1890. [CrossRef] [PubMed]

8. Hong, Y.; Li, S.; Wang, J.; Li, Y. In vitro inhibition of hepatic stellate cell activation by the autophagy-related lipid droplet protein ATG2A. Sci. Rep. 2018, 8. [CrossRef] [PubMed]

9. Zhang, Z.; Zhao, S.; Yao, Z.; Wang, L.; Shao, J.; Chen, A.; Zhang, F.; Zheng, S. Autophagy regulates turnover of lipid droplets via ROS-dependent Rab25 activation in hepatic stellate cell. Redox Biol. 2017, 11, 322-334. [CrossRef] [PubMed]

10. Hernández-Gea, V.; Friedman, S.L. Autophagy fuels tissue fibrogenesis. Autophagy 2012, 8, 849-850. [CrossRef] [PubMed]

11. Jophlin, L.L.; Koutalos, Y.; Chen, C.; Shah, V.H.; Rockey, D.C. Hepatic stellate cells retain retinoid-laden lipid droplets after cellular transdifferentiation into activated myofibroblasts. Am. J. Physiol. Gastrointest. Liver Physiol. 2018. [CrossRef] [PubMed]

12. Testerink, N.; Ajat, M.; Houweling, M.; Brouwers, J.F.; Pully, V.V.; van Manen, H.-J.; Otto, C.; Helms, J.B.; Vaandrager, A.B. Replacement of retinyl esters by polyunsaturated triacylglycerol species in lipid droplets of hepatic stellate cells during activation. PLoS ONE 2012, 7, e34945. [CrossRef] [PubMed]

13. Molenaar, M.R.; Vaandrager, A.B.; Helms, J.B. Some Lipid Droplets Are More Equal Than Others: Different Metabolic Lipid Droplet Pools in Hepatic Stellate Cells. Lipid Insights 2017, 10. [CrossRef] [PubMed]

14. O’Byrne, S.M.; Wongsiriroj, N.; Libien, J.; Vogel, S.; Goldberg, I.J.; Baehr, W.; Palczewski, K.; Blaner, W.S. Retinoid absorption and storage is impaired in mice lacking lecithin:retinol acyltransferase (LRAT). J. Biol. Chem. 2005, 280, 35647-35657. [CrossRef] [PubMed]

15. Kluwe, J.; Wongsiriroj, N.; Troeger, J.S.; Gwak, G.-Y.; Dapito, D.H.; Pradere, J.-P.; Jiang, H.; Siddiqi, M.; Piantedosi, R.; O’Byrne, S.M.; et al. Absence of hepatic stellate cell retinoid lipid droplets does not enhance hepatic fibrosis but decreases hepatic carcinogenesis. Gut 2011, 60, 1260-1268. [CrossRef] [PubMed]

16. O’Byrne, S.M.; Blaner, W.S. Retinol and retinyl esters: Biochemistry and physiology. J. Lipid Res. 2013, 54, 1731-1743. [CrossRef] [PubMed]

17. Saeed, A.; Dullaart, R.P.F.; Schreuder, T.C.M.A.; Blokzijl, H.; Faber, K.N. Disturbed Vitamin A Metabolism in Non-Alcoholic Fatty Liver Disease (NAFLD). Nutrients 2017, 10. [CrossRef] [PubMed] 
18. Bitetto, D.; Bortolotti, N.; Falleti, E.; Vescovo, S.; Fabris, C.; Fattovich, G.; Cussigh, A.; Cmet, S.; Fornasiere, E.; Ceriani, E.; et al. A deficiency is associated with hepatitis $C$ virus chronic infection and with unresponsiveness to interferon-based antiviral therapy. Hepatology 2013, 57, 925-933. [CrossRef] [PubMed]

19. Chaves, G.V.; Pereira, S.E.; Saboya, C.J.; Spitz, D.; Rodrigues, C.S.; Ramalho, A. Association between liver vitamin A reserves and severity of nonalcoholic fatty liver disease in the class III obese following bariatric surgery. Obes. Surg. 2014, 24, 219-224. [CrossRef] [PubMed]

20. Lee, Y.-S.; Jeong, W.-I. Retinoic acids and hepatic stellate cells in liver disease. J. Gastroenterol. Hepatol. 2012, 27 (Suppl. S2), 75-79. [CrossRef] [PubMed]

21. Murakami, K.; Kaji, T.; Shimono, R.; Hayashida, Y.; Matsufuji, H.; Tsuyama, S.; Maezono, R.; Kosai, K.; Takamatsu, H. Therapeutic effects of vitamin A on experimental cholestatic rats with hepatic fibrosis. Pediatr. Surg. Int. 2011, 27, 863-870. [CrossRef] [PubMed]

22. Hisamori, S.; Tabata, C.; Kadokawa, Y.; Okoshi, K.; Tabata, R.; Mori, A.; Nagayama, S.; Watanabe, G.; Kubo, H.; Sakai, Y. All-trans-retinoic acid ameliorates carbon tetrachloride-induced liver fibrosis in mice through modulating cytokine production. Liver Int. 2008, 28, 1217-1225. [CrossRef] [PubMed]

23. Yu, D.; Cai, S.-Y.; Mennone, A.; Vig, P.; Boyer, J.L. Cenicriviroc, a cytokine receptor antagonist, potentiates all-trans retinoic acid in reducing liver injury in cholestatic rodents. Liver Int. 2018, 38, 1128-1138. [CrossRef] [PubMed]

24. Hellemans, K.; Verbuyst, P.; Quartier, E.; Schuit, F.; Rombouts, K.; Chandraratna, R.A.S.; Schuppan, D.; Geerts, A. Differential modulation of rat hepatic stellate phenotype by natural and synthetic retinoids. Hepatology 2004, 39, 97-108. [CrossRef] [PubMed]

25. Fortuna, V.A.; Trugo, L.C.; Borojevic, R. Acyl-CoA: Retinol acyltransferase (ARAT) and lecithin:retinol acyltransferase (LRAT) activation during the lipocyte phenotype induction in hepatic stellate cells. J. Nutr. Biochem. 2001, 12, 610-621. [CrossRef]

26. Yi, H.-S.; Lee, Y.-S.; Byun, J.-S.; Seo, W.; Jeong, J.-M.; Park, O.; Duester, G.; Haseba, T.; Kim, S.C.; Park, K.-G.; et al. Alcohol dehydrogenase III exacerbates liver fibrosis by enhancing stellate cell activation and suppressing natural killer cells in mice. Hepatology 2014, 60, 1044-1053. [CrossRef] [PubMed]

27. Troeger, J.S.; Mederacke, I.; Gwak, G.-Y.; Dapito, D.H.; Mu, X.; Hsu, C.C.; Pradere, J.-P.; Friedman, R.A.; Schwabe, R.F. Deactivation of hepatic stellate cells during liver fibrosis resolution in mice. Gastroenterology 2012, 143, 1073-1083. [CrossRef] [PubMed]

28. Kisseleva, T.; Cong, M.; Paik, Y.; Scholten, D.; Jiang, C.; Benner, C.; Iwaisako, K.; Moore-Morris, T.; Scott, B.; Tsukamoto, H.; et al. Myofibroblasts revert to an inactive phenotype during regression of liver fibrosis. Proc. Natl. Acad. Sci. USA 2012, 109, 9448-9453. [CrossRef] [PubMed]

29. Bansal, M.B. Hepatic stellate cells: Fibrogenic, regenerative or both? Heterogeneity and context are key. Hepatol. Int. 2016, 10, 902-908. [CrossRef] [PubMed]

30. Natarajan, V.; Harris, E.N.; Kidambi, S. SECs (Sinusoidal Endothelial Cells), Liver Microenvironment, and Fibrosis. Biomed. Res. Int. 2017, 2017, 1-9. [CrossRef] [PubMed]

31. Wan, Y.J.; An, D.; Cai, Y.; Repa, J.J.; Hung-Po Chen, T.; Flores, M.; Postic, C.; Magnuson, M.A.; Chen, J.; Chien, K.R.; et al. Hepatocyte-specific mutation establishes retinoid $\mathrm{X}$ receptor alpha as a heterodimeric integrator of multiple physiological processes in the liver. Mol. Cell. Biol. 2000, 20, 4436-4444. [CrossRef] [PubMed]

32. He, Y.; Tsuei, J.; Wan, Y.-J.Y. Biological functional annotation of retinoic acid alpha and beta in mouse liver based on genome-wide binding. Am. J. Physiol. Gastrointest. Liver Physiol. 2014, 307, G205-G218. [CrossRef] [PubMed]

33. Boergesen, M.; Pedersen, T.Å.; Gross, B.; van Heeringen, S.J.; Hagenbeek, D.; Bindesbøll, C.; Caron, S.; Lalloyer, F.; Steffensen, K.R.; Nebb, H.I.; et al. Genome-wide profiling of liver X. receptor, retinoid X. receptor, and peroxisome proliferator-activated receptor $\alpha$ in mouse liver reveals extensive sharing of binding sites. Mol. Cell. Biol. 2012, 32, 852-867. [CrossRef] [PubMed]

34. Dubois-Chevalier, J.; Dubois, V.; Dehondt, H.; Mazrooei, P.; Mazuy, C.; Sérandour, A.A.; Gheeraert, C.; Guillaume, P.; Baugé, E.; Derudas, B.; et al. The logic of transcriptional regulator recruitment architecture at cis-regulatory modules controlling liver functions. Genome Res. 2017, 27, 985-996. [CrossRef] [PubMed]

35. Liu, H.-X.; Hu, Y.; Wan, Y.-J.Y. Microbiota and bile acid profiles in retinoic acid-primed mice that exhibit accelerated liver regeneration. Oncotarget 2016, 7, 1096-1106. [CrossRef] [PubMed] 
36. Shmarakov, I.O.; Jiang, H.; Yang, K.J.Z.; Goldberg, I.J.; Blaner, W.S. Hepatic retinoid stores are required for normal liver regeneration. J. Lipid Res. 2013, 54, 893-908. [CrossRef] [PubMed]

37. Imai, T.; Jiang, M.; Kastner, P.; Chambon, P.; Metzger, D. Selective ablation of retinoid X receptor alpha in hepatocytes impairs their lifespan and regenerative capacity. Proc. Natl. Acad. Sci. USA. 2001, 98, 4581-4586. [CrossRef] [PubMed]

38. Ohata, M.; Yamauchi, M.; Takeda, K.; Toda, G.; Kamimura, S.; Motomura, K.; Xiong, S.; Tsukamoto, H. RAR and RXR expression by Kupffer cells. Exp. Mol. Pathol. 2000, 68, 13-20. [CrossRef] [PubMed]

39. Gonzalez-Sanchez, E.; Firrincieli, D.; Housset, C.; Chignard, N. Expression patterns of nuclear receptors in parenchymal and non-parenchymal mouse liver cells and their modulation in cholestasis. Biochim. Biophys. Acta 2017, 1863, 1699-1708. [CrossRef] [PubMed]

40. Li, Z.; Kruijt, J.K.; van der Sluis, R.J.; Van Berkel, T.J.C.; Hoekstra, M. Nuclear receptor atlas of female mouse liver parenchymal, endothelial, and Kupffer cells. Physiol. Genom. 2013, 45, 268-275. [CrossRef] [PubMed]

41. Uchimura, K.; Nakamuta, M.; Enjoji, M.; Irie, T.; Sugimoto, R.; Muta, T.; Iwamoto, H.; Nawata, H. Activation of retinoic $\mathrm{X}$ receptor and peroxisome proliferator-activated receptor-gamma inhibits nitric oxide and tumor necrosis factor-alpha production in rat Kupffer cells. Hepatology 2001, 33, 91-99. [CrossRef] [PubMed]

42. Marzioni, M.; Saccomanno, S.; Agostinelli, L.; Rychlicki, C.; De Minicis, S.; Pierantonelli, I.; Trauner, M.; Fickert, P.; Müller, T.; Shanmukhappa, K.; et al. PDX-1/Hes-1 interactions determine cholangiocyte proliferative response to injury in rodents: Possible implications for sclerosing cholangitis. J. Hepatol. 2013, 58, 750-756. [CrossRef] [PubMed]

43. Neumann, K.; Kruse, N.; Szilagyi, B.; Erben, U.; Rudolph, C.; Flach, A.; Zeitz, M.; Hamann, A.; Klugewitz, K. Connecting liver and gut: Murine liver sinusoidal endothelium induces gut tropism of CD4+ T cells via retinoic acid. Hepatology 2012, 55, 1976-1984. [CrossRef] [PubMed]

44. Weiskirchen, R.; Tacke, F. Cellular and molecular functions of hepatic stellate cells in inflammatory responses and liver immunology. Hepatobiliary Surg. Nutr. 2014, 3, 344-363. [CrossRef] [PubMed]

45. Ichikawa, S.; Mucida, D.; Tyznik, A.J.; Kronenberg, M.; Cheroutre, H. Hepatic stellate cells function as regulatory bystanders. J. Immunol. 2011, 186, 5549-5555. [CrossRef] [PubMed]

46. D'Ambrosio, D.N.; Walewski, J.L.; Clugston, R.D.; Berk, P.D.; Rippe, R.A.; Blaner, W.S. Distinct populations of hepatic stellate cells in the mouse liver have different capacities for retinoid and lipid storage. PLoS ONE 2011, 6, e24993. [CrossRef] [PubMed] 